Pirineos.Revista de Ecología de Montaña Vol. 166, 123-133

Jaca, Enero-Diciembre, 2011

ISSN: 0373-2568

eISSN: 1988-4281

doi: 10.3989/ Pirineos.2011.166006

\title{
USING BLOCK COUNTS AND DISTANCE SAMPLING TO ESTIMATE POPULATIONS OF CHAMOIS
}

\author{
J. Herrero ${ }^{1}$, A. García-Serrano ${ }^{2}$, C. Prada ${ }^{2} \&$ O. Fernández-Arberas ${ }^{2}$ \\ 1 Area of Ecology. Technical School of Huesca. University of Zaragoza. E-22071 Huesca \\ herreroj@unizar.es \\ 2 Ega Wildlife Consultants. Sierra de Vicort, 31, 1. ${ }^{\circ}$ A. E-50003 Zaragoza \\ egasl@arrakis.es
}

\begin{abstract}
This study compared the efficacies of total block counts (BC) and distance sampling (DS) procedures to estimate the abundance of chamois populations in two mountain massifs, Posets and Maladeta, Spain. In 2002, 2006, 2007, and 2008, chamois populations were surveyed along itineraries above the timberline, twice per year: in July, after the parturition period, and in November, during the rut. The latter survey was used to estimate the sex ratio and to correct the proportion of males present in July. In 2008, poor weather prevented surveys in November. In the $D S$ procedure, we used the data collected using $B C$ and calculated the distances of the mapped groups to the itinerary, using a Geographical Information System. In Posets, estimates of population densities derived using BC ranged from 5.5 to 9.1 chamois $\mathrm{km}^{-2}$, while those derived using DS ranged from 7.5 to 9.7 chamois $\mathrm{km}^{-2}$. In Maladeta, the estimates ranged from 3.4 to 5.4 chamois $\mathrm{km}^{-2}$ (BC) and from 4.6 to 8.5 chamois $\mathrm{km}^{-2}(D S)$. Coefficients of variation of DS ranged between $14 \%$ and $26 \%$. In five of eight cases the counts of population size derived from BC were within the $95 \%$ confidence interval of the estimate derived from DS. In two of the other three cases, weather conditions created poor visibility during the rut, and few chamois were seen and, consequently, the rut sex ratio could not be estimated. BC provided objective, high-quality counts of chamois populations and it is easy to obtain, even if its efficacy can be constrained by the need of simultaneous itineraries and an underestimation of unknown magnitude. DS does not require sampling throughout the entire area above the timberline, and generates an estimate and a confidence interval; however, calculations require some skill and sample size must be high ( $n>300$ groups observed to produce a $C V<15 \%$ ), which represents a sampling effort at least as large as the one derived from $B C$. $B C$ represents a valuable tool and, it should continue to be used to estimate minimum population size and the derived hunting quotas.
\end{abstract}

Keywords: Rupicapra p. pyrenaica, block count, distance sampling, above the timberline, mountain environments, mountain ungulates, Pyrenees. 
J. HERRERO, A. GARCÍA-SERRANO, C. PRADA \& O. FERNÁNDEZ-ARBERAS

RESUMEN.- Se comparan los resultados de estimar la abundancia de sarrio aplicando el conteo simultáneo supraforestal (BC) y el muestreo de distancias (DS) a lo largo de itinerarios, durante cuatro años $(2002,2006,2007$ y 2008) en dos macizos pirenaicos, Posets y Maladeta. Se realizaron dos operaciones anuales, una en julio (tras la paridera) y otra en noviembre (en el celo), esta última para conocer la proporción de sexos que se utiliza para corregir el número de sarrios adultos de julio. En 2008 la operación de noviembre no se pudo realizar por inclemencias meteorológicas. Para el DS se utilizan los datos del BC, calculando las distancias perpendiculares al recorrido de los grupos observados y cartografiados, con la ayuda de un Sistema de Información Geográfica. Las densidades de julio de Posets oscilaron entre 5,5 y 9,1 sarrios $\mathrm{km}^{-2}$ (BC) y entre 7,5 y 9,7 sarrios $\mathrm{km}^{-2}$ (DS) y en Maladeta entre 3,4 y 5,4 sarrios $\mathrm{km}^{-2}(B C)$ y entre 4,6 y 8,5 sarrios $\mathrm{km}^{-2}(D S)$, con coeficientes de variación (CV) del DS del 14 al 26\%. El número de animales mínimo estimado con el BC está dentro del intervalo de confianza del 95\% de la densidad calculada por el DS en 5 de los 8 casos. En los otros tres casos, las condiciones meteorológicas adversas durante el celo no hicieron posible el cálculo de la sex ratio. El BC aporta un número objetivo de indudable calidad y su cálculo es sencillo aunque cuenta con el inconveniente de la necesaria simultaneidad en la realización de los recorridos, la coincidencia para ello de buenas condiciones de visibilidad y la existencia de una subestima de magnitud desconocida. El DS, sin embargo, no requiere batir todo el territorio supraforestal y produce una estima de la densidad con su intervalo de confianza. No obstante, el cálculo numérico requiere cierta destreza y dedicación y el tamaño muestral debe ser elevado ( $n>300$ grupos avistados para un $\mathrm{CV}<15 \%$ ) que supone un esfuerzo de muestreo al menos igual al que se realiza en el BC. El BC constituye una herramienta valiosa y su uso debería continuar para estimar el tamaño mínimo poblacional y los cupos de caza derivados.

Palabras clave: Rupicapra p. pyrenaica, conteo simultáneo, muestreo de distancias, ambientes supraforestales, montañas, ungulados de montaña, Pirineos.

\section{Introduction}

Historically, populations of mountain ungulates such as chamois Rupicapra sp. (Berducou, 1982; García-González et al., 1992,) and Iberian wild goat Capra pyrenaica (Pérez et al., 2002) have been monitored and quantified using coordinated block counts (BC), a type of total counts in which several observer teams beat the complete study area simultaneously, which are performed when the weather is favorable (e.g., good visibility, lack of strong wind, rain, or snow). In areas that have dense tree or shrub vegetation, the ability to detect animals can be restricted and BC can significantly underestimate population size (Housin et al., 1994; Cano et al., 2009). The effects of low visibility are overcome by performing observations from vantage points in 
rocky areas (Escós \& Alados, 1988) using a Distance Sampling (DS) procedure (Buckland et al., 2001) along itineraries in open areas (Moço et al., 2006; Pérez et al., 2002) or mainly forested areas (García-González et at., 1992; Garín \& Herrero, 1997).

Recently new experiences with mountain ungulates have been undertaken using itineraries (Cano et al., 2009; Afonso et at., 2008; Monteiro et al., 2010). DS might have advantages over BC because, in the former, not all of the individuals have to be counted to generate a reliable estimate of a population and, theoretically, the time and cost of fieldwork will be less than with the BC procedure. In addition, DS generates an estimate of population density that has a given precision (Borchers et al., 2002).

The vast majority of chamois populations are hunted (Aulagnier et al., 2008; Herrero et álli, 2008). Even non-huntable populations within protected areas are hunted when they venture outside these areas to make altitudinal migrations (Pañella et al., 2010). The prudent or responsible use of this important wildlife resource relies on accurate estimates of population sizes, and the efficacy of BC above the timberline has not been evaluated thoroughly. BC produces estimates of the minimum number of animals that occupy the open areas above the timberline, but the extent to which this procedure underestimates population size is unknown. Although $\mathrm{BC}$ is the main procedure for the long-term monitoring and management of populations, uncertainty over the magnitude of the underestimation raises questions about the quality of the data. For that reason, this study evaluated the efficacy of BC and DS in estimating chamois populations in open areas above the timberline, as part of the long-term monitoring of Pyrenean chamois organized in Aragon and Navarre by their Regional Governments.

\section{Study area}

Chamois populations were surveyed in two mountain massifs in the Spanish Pyrenees, Posets and Maladeta (Fig. 1). Mountain massifs are the natural management units in the region. In Posets and Maladeta, the amounts of area above 1,600 m a.s.l. are 21,199 ha and 28,964 ha, respectively, and most lies within Posets - Maladeta Nature Park, where the highest elevation is $>3,000 \mathrm{~m}$. In our study in the Pyrenees, all of the area above $1,600 \mathrm{~m}$ was considered suitable habitat for chamois, which facilitated comparisons between massifs, rather than between administrative units (Herrero et al., 2002). In the villages in the valley between the massifs, average annual precipitation is $1,215 \mathrm{~mm}$. The vegetation is mainly forests of mountain pine Pinus uncinata, with Rhododendron ferrugineum shrubs. Above the timberline, over 2,000 m, 


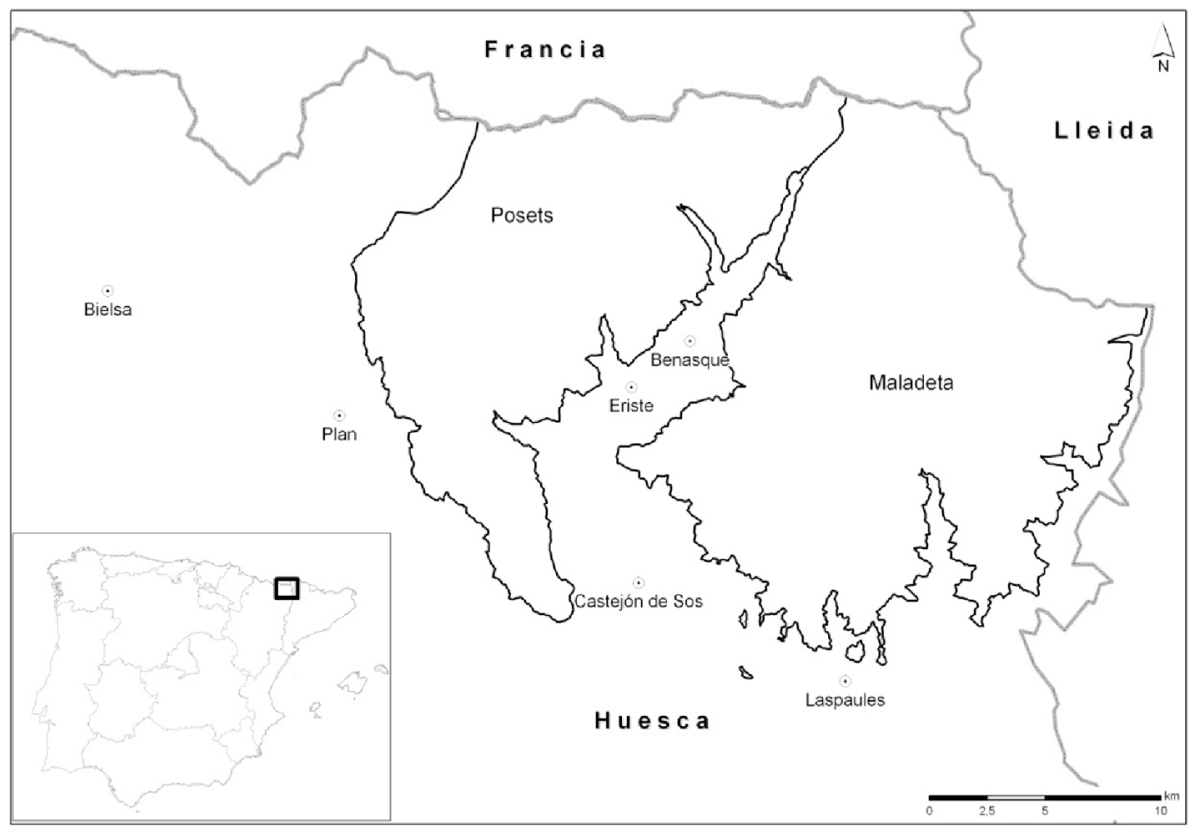

Figure 1. Study area.

Figura 1. Área de estudio.

the habitat is pasture and rocky areas. Prominent fauna in the region include bearded vulture Gypaetus barbatus, golden eagle Aquila chrysaetos, rock ptarmigan Lagopus mutus, and other wild ungulates such as wild boar Sus scrofa and roe deer Capreolus capreolus. Traditional economic activities are livestock farming and forest exploitation although, today, the main economic activity is tourism. Game hunters mainly target ungulates.

\section{Materials and methods}

BC (Berducou et al., 1982) involve counting animals simultaneously in open habitats, with natural features such as massifs as the sampling unit. In our study, typically, pairs of rangers with experience with chamois and the area performed the counts. Each pair of observers had binoculars, spotting scopes, specific cartography, and experience with chamois and the area. In the analysis, duplicate counts were removed based on the groups mapped. 
Estimates of minimum population size were derived from two surveys: one in July, after parturition, which estimated the number of females, yearlings, and kids, and another in November, during the rut, which estimated the number of adult males. The rut sex-ratio is applied to the females seen in July to estimate the number of males. Using this estimation we calculate the density of chamois. During four years (2002, 2006, 2007 and 2008), the chamois populations in the Posets and Maladeta mountain massifs, Spanish Pyrenees were surveyed using the BC procedure. In 2008, poor weather prevented a suitable survey in November.

DS comprises a set of methods for estimating the density of biological populations (Buckland et al., 2001; Thomas et al.,, 2002, 2010). Some surveys of chamois populations have used the line-transect method, in which the observers perform a standardized visual survey along a series of itineraries, searching for objects of interest (in this case, individual or groups of chamois) and recording on a map their location. The objective in the DS procedure is to fit a detection function, $g(y)$, to the observed distances, which reflects the probability that a cluster is detected, given that it is at distance $y$ from the transect line. The fitted function is used to estimate the proportion of objects that were missed by the survey, which contributes to more accurate estimates of population size and structure. The surveys were analyzed using the software Distance (http://www.ruwpa.st-and.ac.uk/distance). The DS procedure has three main assumptions: (1) all of the individuals on the route are detected with certainty, (2) the distance between an animal or groups of animals and the transect is measured accurately, and (3) animals do not move in response to the presence of the observer. Another assumption is that the locations of animals are independent of the locations of the survey routes, which will be met if there is a sufficient number of transects and they are randomly distributed (Thomas et al.,, 2010). In this study, there were two factors to consider: randomly distributed line transects cannot be used in rugged mountain environments, and itineraries are used instead, and observers have to have experience with the terrain, chamois, and its habits, locally.

The DS procedure was used retrospectively in calculating the distances between groups of chamois and the itinerary using a Geographic Information System. We used ArcView software to calculate the perpendicular distance between the itineraries and the chamois or the center of detected groups during the counts using the $\mathrm{BC}$ method. The data were analyzed using Distance 5 (Thomas et al., 2006). The detection function was selected from among a set of suite of parametric distribution models: uniform, half-normal, and hazardrate, which included adjustment terms to improve the fit (cosine expansion). We chose the model that fit best Akaike's Criteria (AIC); viz., low coefficient of variation $(\mathrm{CV})$, small number of parameters, and statistical non-significance. 


\section{Results}

In the Posets and Maladeta mountain massifs, 14 samplings were undertaken (Table 1). In calculating the estimates of population density with DS procedure, the $5 \%$ of the groups that were farthest from the itineraries were excluded. The detection functions were half-normal $(n=6)$ and hazard rate $(\mathrm{n}=8)$ with a cosine expansion. CVs were $14-23 \%$, except for Posets in July $2002(\mathrm{CV}=26 \%)$, when poor weather limited to 15 the number of itineraries. To reduce it to $10 \%$, the distance covered by all of the itineraries should be 320 $\mathrm{km}$, which reflects a $33 \%$ greater sampling effort.

In the three years in which both annual surveys occurred in both of the massifs, the CI 95\% of the estimate of population density derived from DS in July and November overlapped and the first included the estimates derived from BC in five of the six site-years (Table 1). In Maladeta 2002 the estimate from BC were very near the DS lower confidence interval limit. In 2008, during the rut, weather conditions did not permitted doing the itineraries correctly and the adult sex ratio could not be estimated. In this case the BC estimates were very near the DS lower confidence interval limit (Figure 2).

\section{Discussion}

Aspects of the retrospective analysis of BC data using DS are relevant to the monitoring and management of Rupicapra populations. The calculated CV can be considered small (Franzetti \& Foccardi, 2006), and more precise population estimate require a much larger sampling effort, which is impractical in many cases by the existing ranger staff. Coordinated monitoring of chamois populations in both regions involves 16 mountain massifs (Herrero et al., 2004), of which only five have enough chamois at a sufficiently high density to be able to have a DS analysis given the current sampling effort. Other problems to overcome when DS is used are: (i) the need for technical experience in data analysis, (ii) the deskwork derived from fieldwork, which increases the cost of the monitoring program, and (iii) the need for a number of longrange telemeters, which are expensive. The estimates derived from $\mathrm{BC}$ were not appreciably different from the estimates derived using DS, which indicates that the underestimation bias of $\mathrm{BC}$ is small and this has a consequence for management: hunting quotas are based on population sizes that probably were not significantly underestimated. Thus, the data from $B C$ can remain the primary source of information when annual hunting quotas are set.

We conclude that, with the sampling effort used in our study, the DS procedure can be applied in few massifs where chamois are numerous and at a 


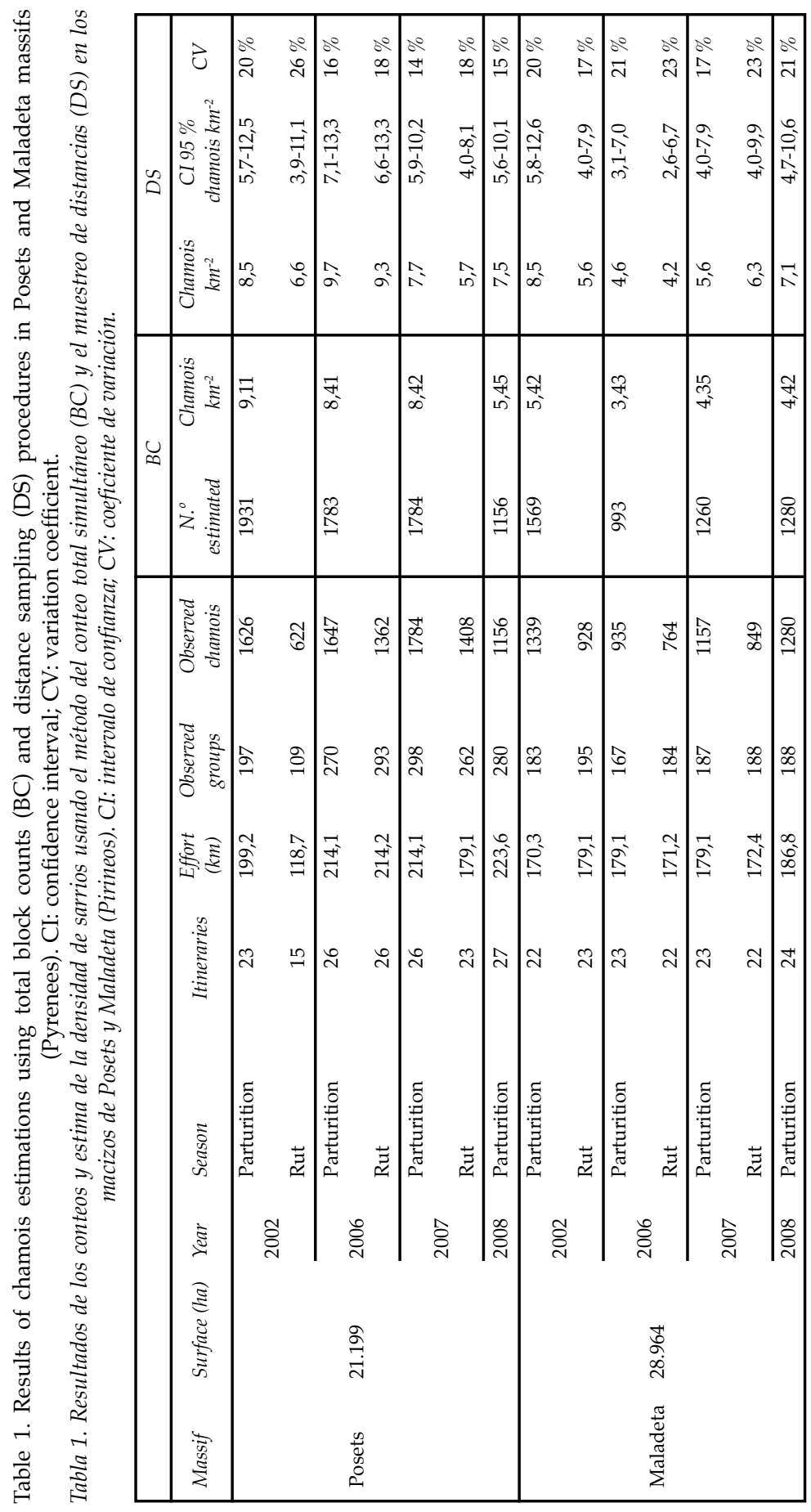

(Pirineos, 2011, Vol. 166, 123-133, ISSN 0373-2568, eISSN: 1988-4281, doi: 10.3989/Pirineos.2011.166006) 


\section{Posets}

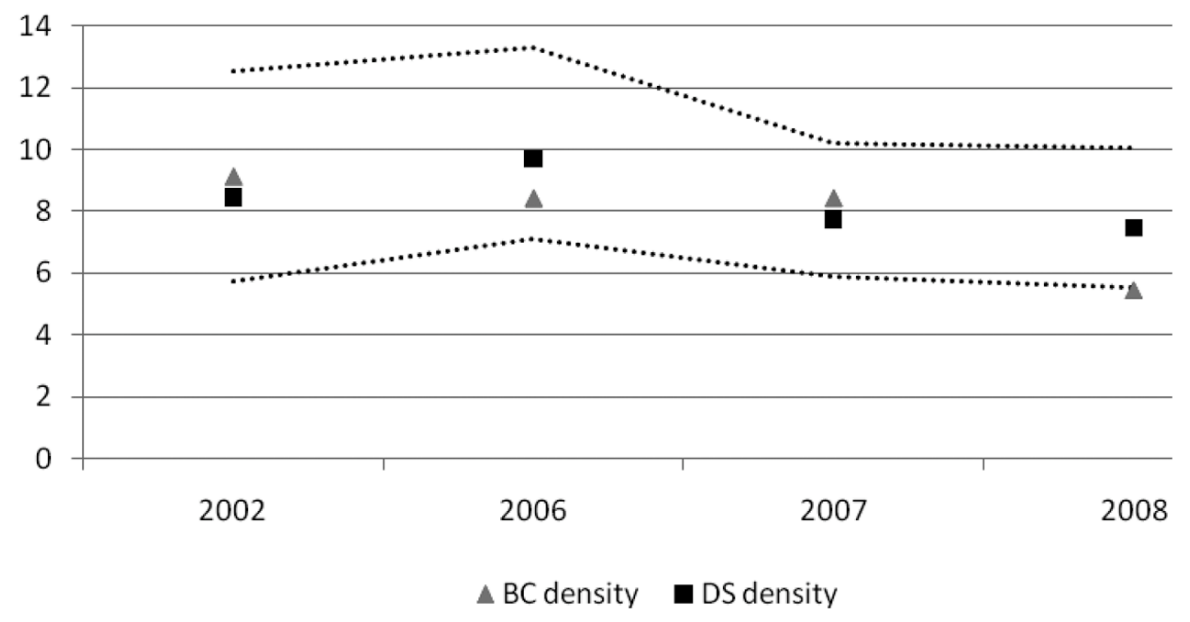

Maladeta

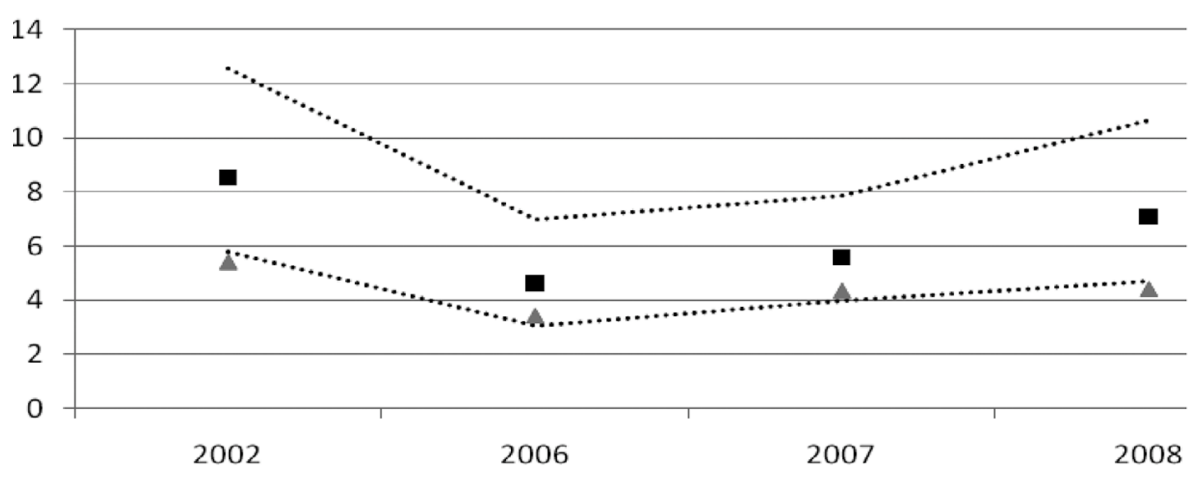

Figure 2. Block Count (BC) and Distance Sampling (DS) derived estimates of chamois population densities (chamois $\mathrm{km}^{-2}$ ) in Posets and Maladeta, Spain. DS calculated in June. Dotted lines represent $95 \%$ CI of DS.

Figura 2. Densidad estimada con el conteo simultáneo supraforestal (BC) y el muestreo de distancias (DS) de la población de sarrios en Posets y Maladeta, España. DS calculado con los datos de junio. Las líneas discontinuas representas el IC del 95\% del DS.

high density. Surveys should continue to be performed in July and November and DS should be applied in other massifs to confirm whether BC underestimate population sizes. 


\section{Acknowledgments}

This research was the product of the ongoing, long-term monitoring of chamois populations in Aragon and Navarre (Pyrenees, Spain. We greatly appreciate the invaluable contribution made by the rangers in Posets and Maladeta.

\section{References}

Afonso, A., Alpizar-Jara, M., Moço, G., Granados, J.E., \& Pérez, J.M., 2008. Dimensión de la muestra y estimación de la variancia en muestreo por distancias: una aplicación en la estima de abundancia de poblaciones de ungulados de montaña. In: J.E. Granados, J. Cano-Manuel León, P. Fandos París, R. Cadenas de Llano Aguilar (Eds.). Tendencias actuales en el Estudio y Conservación de los Caprinos Europeos. Junta de Andalucía, Consejería de Medio Ambiente. Pp. 15-30.

Aulagnier, S., Giannatos, G. \& Herrero, J., 2008. Rupicapra rupicapra. In: IUCN Red List of Threatened Species. Version 2010.4. <www.iucnredlist.org>. Downloaded on 19 November 2010

Berducou, C., Besson, C., \& Guardas monitores del PNP, 1982. Dynamique des populations d'isards du Parc National des Pyrénées. Acta Biologica Montana 1: 153-175.

Borchers, D. L., Buckland, S.T. \& Zucchini, W., 2002. Estimating animal abundance. Closed populations. Springer-Verlag, London, U.K.

Buckland, S.T., Anderson, D.R., Burnham, K.P., Laake, J.L., Borchers, D.L. \& Thomas, L., 2001. Introduction to distance sampling. Oxford University Press, Oxford, U.K.

Cano, M., García-Rovés, P., González-Quirós, P. \& Nores, C., 2009. Experiencias de estimación de poblaciones de rebeco en la Cordillera Cantábrica. En: F.J. Pérez-Barbería y B. Palacios (Eds.). El rebeco cantábrico Rupicapra pyrenaica parva. Conservación y Gestión de sus poblaciones. Naturaleza y Parques Nacionales. Serie Técnica.

Escós, J. \& Alados, C.L., 1988. Estimating mountain ungulate density in Sierras de Cazorla y Segura. Mammalia, 52(3): 425-428.

Franzetti, B. \& Focardi, S., 2006. La stima di popolazione degli ungulati mediante Distance sampling e termocamera a infrarossi. Min. Politiche Agricole, Alimentari e Forestali - Ist. Naz. Fauna Selvatica, Documenti Tecnici, 26: $1-88$.

García-González, R., Hidalgo, R., Herrero, J. \& Ameztoy, J.M., 1992. Census, population structure and habitat use of a chamois population living in 
sympatry with Pyrenean wild goat. In: Ongulés/Ungulates. 91. Pp. 321-325. F. Spitz, G. Janeau, G. Gonzalez and S. Aulaguier (Eds). SFEPM-IRGM. Paris, Toulouse.

Garin, I. \& Herrero, J., 1997. Distribution, abundance and demographic parameters of the Pyrenean chamois (Rupicapra p. pyrenaica) in Navarre, Western Pyrenees. Mammalia, 61(1): 55-63.

Herrero, J., Escudero, E., García, J.M., García-Serrano, A., Prada, C. \& Couto, S., 2004. Gestión y seguimiento demográfico del sarrio en el Pirineo aragonés. In: J. Herrero., E. Escudero, D. Fernández de Luco, R. GarcíaGonzález (Eds.). El sarrio: biología, patología y gestión. Consejo de Protección de la Naturaleza de Aragón, Gobierno de Aragón, Zaragoza. Pp. 69-82.

Herrero, J., Lovari, S. \& Berducou, C., 2008. Rupicapra pyrenaica. In: IUCN Red List of Threatened Species. Version 2010.4. <www.iucnredlist.org>. Downloaded on 19 November 2010.

Houssin, H., Loison, A., Jullien, J.M. \& Gaillard, J.M. 1994. Validité de la méthode du pointage-flash pour l'estimation des effectifs de chamois (Rupicapra rupicapra). Gibier Faune Sauvage, 11 (4): 287-298.

Moço, G., Guerreiro, M., Ferreira, A.F., Rebelo, A., Loureiro, A., PetrucciFonseca, F. \& Pérez, J.M., 2006. The ibex Capra pyrenica returns to its former Portuguese range. Oryx, 40 (3): 351-354.

Monteiro, J.F., Alpizar-Jara, R., Serrano, E., Crampe, J.P. \& Pérez, J.M., 2008. Estimación Bayesiana de $g_{o}$ usando el muestreo por distancias y su aplicación en las estimas de densidad de ungulados de montaña. In: J. Granados, J. Cano-Manuel León, P. Fandos París, R. Cadenas de Llano Aguilar (Eds.). Tendencias actuales en el Estudio y Conservación de los Caprinos Europeos. Junta de Andalucía, Consejería de Medio Ambiente. Pp 207-218.

Pañella, P., Herrero, J., Canut, J. \& García-Serrano, A., 2011. Long-term monitoring of Pyrenean chamois in a protected area reveals a fluctuating population. Hystrix (in press).

Pérez, J.M., Granados, J.E., Soriguer, R.C., Fandos, P., Márquez, F.J. \& Crampe, J.-P., 2002. Distribution, status and conservation problems of the Spanish Ibex, Capra pyrenaica (Mammalia: Artiodactyla) Mammal Review, 32(1): 26-39.

Thomas, L., Buckland, S.T., Burnham, K.P., Anderson, D.R., Laake, J.L., Borchers, D.L. \& Strindberg, S., 2002. Distance sampling. In: El-Shaarawi A.H, and W.W. Piegorsch (Eds). Encyclopedia of Environmetrics. Volume 1, pp 544-552.

Thomas, L., Laake, J.L., Strindberg, S., Marques, F.C., Buckland, S.T., Borchers, D.L., Anderson, D.R., Burnham, K.P., Hedley, S.L., Pollard, J.H., Bishop, J.R.B. \& Marques, T.A., 2006. Distance 5.0. Release 2. Research Unit 
USING BLOCK COUNTS AND DISTANCE SAMPLING TO ESTIMATE POPULATIONS OF CHAMOIS

for Wildlife Population Assessment, University of St. Andrews, UK. http:/ / www.ruwpa.st-and.ac.uk/distance/.

Thomas, L., Buckland, S., Rexstad, E.A., Laake, J.L., Strindberg, S., Hedley, S.L., Bishop, J.R.B., Marques, T.A. \& Burnham, F.P., 2010. Distance Software: design and analysis of distance sampling surveys for estimating population size. Journal of Applied Ecology, 47: 5-14. 